\title{
Anatomical and genetic aspects of ash dieback: a look at the wood structure
}

\author{
Mirela Tulik ${ }^{(1)}$, \\ Jacek Zakrzewski ${ }^{(1)}$, \\ Jacek Adamczyk ${ }^{(2)}$, \\ Anna Tereba ${ }^{(3)}$, \\ Barbaros Yaman ${ }^{(4)}$, \\ Justyna A Nowakowska ${ }^{(3)}$
}

\section{Introduction}

European ash (Fraxinus excelsior L.) is spread almost throughout Europe, with the exception of central and southern Spain, northern part of the Scandinavian peninsula, Iceland and northern regions of the British Isles (Pautasso et al. 2013). It is most common in lowland forests, but in the submontane and lower montane layers it usually occurs in the alder-ash or elm-ash forests from the alliance Alno-Ulmion. The ecological significance of ash has recently

\begin{abstract}
Pathogen diseases are increasingly threatening forest trees under the current climate change, causing a remarkable decrease in the stability of forest ecosystems. Ash (Fraxinus excelsior L.) dieback due to Hymenoscyphus fraxineus has been noted in Poland since 1992 and has spread over many European countries. The aim of this study was to test the hypothesis that ash trees af fected by dieback could exhibit a reduced vessel size and density along the trunk, as well as a lowered width of annual wood rings, leading to the weakening of water transport towards the crown. Dead and dying ash trees were sampled in a forest district severely affected by ash decline in southern Poland. Wood samples were collected at different height along the trunk and several wood anatomical characteristics of annual tree rings over the period 20022011 were examined. Dead trees showed a stronger reduction in radial growth than dying trees over the period considered. Moreover, the diameter of vessels increased from the crown to the base in both dead and dying trees, while the density decreased. Significant differences between dead and dying trees were detected in size and density of vessels in the period analyzed, as well as in the width of annual rings. DNA extracted from wood samples was analyzed using SSR markers and the main genetic parameters of dead and dying trees were estimated, finding similar levels of polymorphism and only slight non-significant differences between the two health groups. Our results are consistent with the hypothesis that pathogens could disrupt the hormonal control of wood formation by interfering with the polar auxin transport, progressively leading to the death of ash trees.
\end{abstract}

Keywords: Ash Trees, Microsatellites Markers, Tree Decline, Wood, Vessel Size and Density

increased because of the Dutch elm disease (Brasier 1991) as well as alder dieback caused by microorganisms belonging to Phytophtora genus (Brasier et al. 1999). However, the first symptoms of ash decline were noticed in Poland since 1992, especially in the north-east region (Stocki 2001), and rapidly spread across Poland (Kowalski 2006) over an area of more than 10,000 hectares (Gil et al. 2006). Today, the ash decline has become chronic and was observed not only in most European coun-
(1) Department of Forest Botany, Warsaw University of Life Sciences (SGGW-WULS), 159 Nowoursynowska St., 02-776 Warsaw (Poland); (2) Institute of Forest Science of Lodz University, 65/67 Konstytucji 3 Maja St. 97-200 Tomaszów Mazowiecki (Poland); (3) Laboratory of Molecular Biology, Forest Research Institute, 3 Braci Lesnej St., Sekocin Stary, 05-090 Raszyn (Poland); (4) Wood Anatomy and Dendrochronology Laboratory, Bartin University, Bartin (Turkey)

@ Mirela Tulik (mirela.tulik@wl.sggw.pl)

Received: Apr 08, 2016 - Accepted: Jan 21, 2017

Citation: Tulik M, Zakrzewski J, Adamczyk J, Tereba A, Yaman B, Nowakowska JA (2017). Anatomical and genetic aspects of ash dieback: a look at the wood structure. iForest 10: 522528. - doi: 10.3832/ifor2080-010 [online 2017-04-20]

Communicated by: Vicente Rozas tries (Pliura et al. 2015) but also in Asia and North America (Bricker \& Stutz 2004, Ward et al. 2006). Currently, it is assumed that ash dieback is due to Hymenoscyphus fraxineus Baral, Queloz \& Hosoya (Baral et al. 2014) (= anamorphe Chalara fraxinea T. Kowalski 2006), a novel species alien to Poland (Kowalski \& Holdenrieder 2009). A broad range of symptoms resulting from ash dieback disease involves all parts of the tree, including necrotic lesions and cankers along the bark of branches and stem, wilt and discoloration of foliage, dieback of shoots, twigs or trunk, as well as epicormic branching or excessive side shoots along the trunk (Bakys et al. 2009, Kirisits \& Freischlang 2012). Discoloration of the bark was also observed (Thomsen \& Skovsgaard 2012).

Ash tree has a ring-porous wood and vessel formation is controlled by a mechanism associated with the polar transport of auxin (Jacobs 1952, Sachs 1981, Little \& Pharis 1995), which is conditioned by the asymmetrical distribution of auxin carriers on the cell membrane (Muday \& Morphy 2002). Auxin is thought to be produced by developing buds and young growing leaves and its effect on vessel differentiation can be altered by providing exogenous auxin (Digby \& Wareing 1966, Zakrzewski 1991). 
Aloni \& Zimmermann (1983) observed that vessel size in wood increases from leaves to roots, while their density decreases, and ascribed this pattern to a decreasing gradient of auxin concentration downwards. Based on the above hypothesis, high auxin levels close to young leaves induce a rapid differentiation and the formation of small vessels. Conversely, low concentrations of auxin result in a slow differentiation and the formation of wider vessels. Wolpert (1996) proposed that concentration gradients of morphogens are important for the regulation of developmental events in animals. Under this assumption, cells develop in relation to their position along a concentration gradient of a morphogen. This assumption has also been adopted for plants as a mechanism able to coordinate the development of plant cells. It stipulates that auxin, whose concentration decreases in basipetal direction, could act as a positional signal for the differentiation of cambial derivatives as new vessels (Uggla et al. 1998).

A well-developed set of vessels ensures the proper transport of water to all tree organs and allows for their survival in unfavorable environmental conditions. In ringporous species like ash the vessels involved in the transport of water are those located in the earlywood of the current year (Ellmore \& Ewers 1986) which loose their functionality by the end of each winter (Zimmermann 1983). The contribution of earlywood vessels to water transport in ring-porous species is approx. $90 \%$ (Corcuera et al. 2006).

The foliage of ash trees subjected to decline is strongly affected by Hymenoscyphus fraxineus and other secondary harmful agents, though varying levels of the disease symptoms could be observed. Such variation in the susceptibility of trees to decline may be hypothesized to reflect changes in water transport along the trunk and/or to genetically-encoded resistance to the fungus.

In this study we aimed to test the following working hypotheses: (1) ash trees affected by decline have a reduced radial increment, with decreasing annual tree ring width and variation along the trunk of the size and density of tracheary elements, according to Aloni \& Zimmermann (1983); (2) different disease symptoms may be due to differences in the genetic make-up of ash

Tab. 1 - Mean biometric traits ( \pm standard deviation) of the European ash trees sampled for anatomic and genetic analyses, grouped by health status of the trees. $(A B H)$ : Age at the breast height (years); (DBH): diameter at breast height $(\mathrm{cm}) ;(\mathrm{HCB})$ : height of the crown base $(\mathrm{m})$.

\begin{tabular}{llccc}
\hline $\begin{array}{l}\text { Health } \\
\text { class }\end{array}$ & Symptoms of dieback & $\begin{array}{c}\text { ABH } \\
(\mathrm{yrs})\end{array}$ & $\begin{array}{c}\text { DBH } \\
(\mathrm{cm})\end{array}$ & $\begin{array}{c}\text { HCB } \\
(\mathrm{m})\end{array}$ \\
\hline dying & $\begin{array}{l}\text { defoliating - 70\%, top dry or foliage } \\
\text { wilting }\end{array}$ & $60 \pm 6.93$ & $26 \pm 2.08$ & $20 \pm 3.47$ \\
& $\begin{array}{l}\text { cambium necrosis, withered branches } \\
\text { without leaves }\end{array}$ & $75 \pm 0.58$ & $28 \pm 0.58$ & $21 \pm 2.31$ \\
\hline dead & & & \\
\hline
\end{tabular}

ered. We measured the width of annual tree rings, and the diameter and density of earlywood vessels in the rings. Measures were averaged over each health class for the following variables: (i) the width of annual tree rings; (ii) the number of earlywood vessels along the boundary of annual tree rings (amounting to $6.65 \mathrm{~mm}$ for each ring); (iii) the diameter of earlywood vessels (overall 4800 vessels); (iv) the density of earlywood vessels (number of vessels per $1 \mathrm{~mm}^{2}$ of annual increment; $(v)$ the surface area of earlywood vessels; (vi) the ratio of the surface area of earlywood vessels to the width of annual tree ring (expressed in \%). The annual tree rings formed during the course of ash dieback were mainly composed of earlywood, as latewood zones were diminished or absent; therefore only the diameter of earlywood vessels was examined.

The mean value of each variable was calculated for each annual tree ring over the calendar years 2002-2011 and for all rings at the selected heights $\left(\mathrm{H}_{1}, \mathrm{H}_{2}, \mathrm{H}_{3}, \mathrm{H}_{4}\right)$. Differences between health classes for each variable were tested using an independent samples $t$-test, with $p \leq 0.005$ as threshold for the significance of differences.

\section{Genetic analyses}

A preliminary analysis of genetic diversity based on neutral microsatellite markers was carried out on 6 trees representing the two health classes (3 dead trees and 3 dying trees). DNA was extracted from wood samples using the NucleoSpin ${ }^{\oplus}$ Plant II kit (Macherey-Nagel, Düren, Germany), following the manufacturer's protocol with small modifications (i.e., the volume of the three buffers was changed: $600 \mu \mathrm{l}$ of PL2, $150 \mu \mathrm{l}$ of PL3 and $900 \mu \mathrm{l}$ of P( buffer). Six nuclear microsatellite and four chloroplast loci were amplified in two multiplexes, using the Multiplex $\mathrm{PCR}^{\oplus}$ Kit (Qiagen, Hilden, Germany). In multiplex $A$ the amplified loci were: Femsatl-4, Femsatl-8, Femsatl-19, ccmp3, ccmp6; in multiplex B were Femsatl-11, Femsatl-16, M2-30, ccmp7, and ccmp10 (for details on primer sequences, see Sutherland et al. 2010). PCR reactions were carried out in $10 \mu \mathrm{l}$ reaction volumes with 5-50 ng DNA, $10 \mathrm{pmol}$ of each primer, $5 \mu$ l Multiplex PCR Master Mix ${ }^{\circledR}$ (Qiagen). Each forward primer was labelled with fluorescent WellRED ${ }^{\oplus}$ dyes (Beckman Coulter Inc., Brea, CA, USA). The PCR thermal profile followed the protocols used by Sutherland et al. (2010) for both multiplexes. Allele lengths were scored on the CEQ $8000^{\circledR}$ sequencer (Beckman Coulter, Inc.). Parameters of genetic variation were computed for each health class (dead and dying trees) using the software GenAlEx v.6.502 (Peakall \& Smouse 2006). Differences in genetic parameters between health classes and among trees were tested by the analysis of molecular variance (AMOVA) using GenAIEx v.6.502 (999 permutations, $p=0.01)$. 
Fig. 1 - Cross section of wood of a dying ash tree taken at $1.3 \mathrm{~m}$ above the ground. A reduction in the extension of latewood can be noticed for more recent annual rings (on the left).

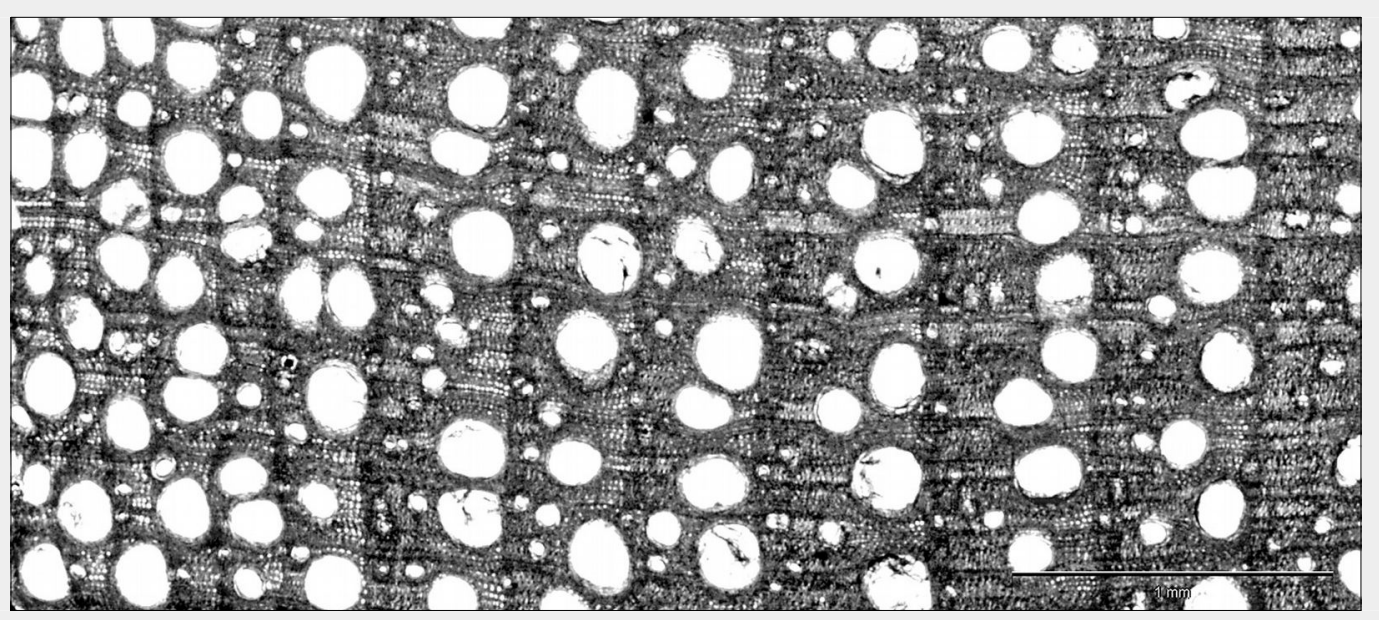

Fig. 2 - Variation in width of annual tree rings in the health classes of ash trees affected by dieback (white bars: dying trees; grey bars: dead trees). (a): different heights along the trunk ( $\mathrm{H}_{1}: 1.3 \mathrm{~m}$ above the ground; $\mathrm{H}_{2}: 10 \mathrm{~m}$ above the ground; $\mathrm{H} 3: 2$ m below the crown base; $\mathrm{H} 4$ : close to the crown base); (b): different years over the period 2002-2011.

(a)

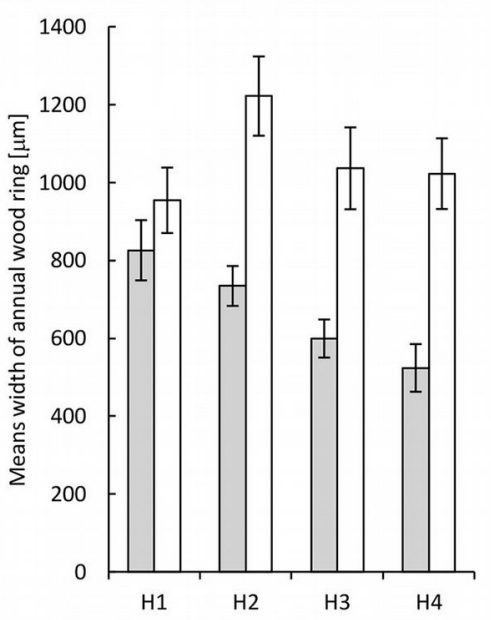

(b)

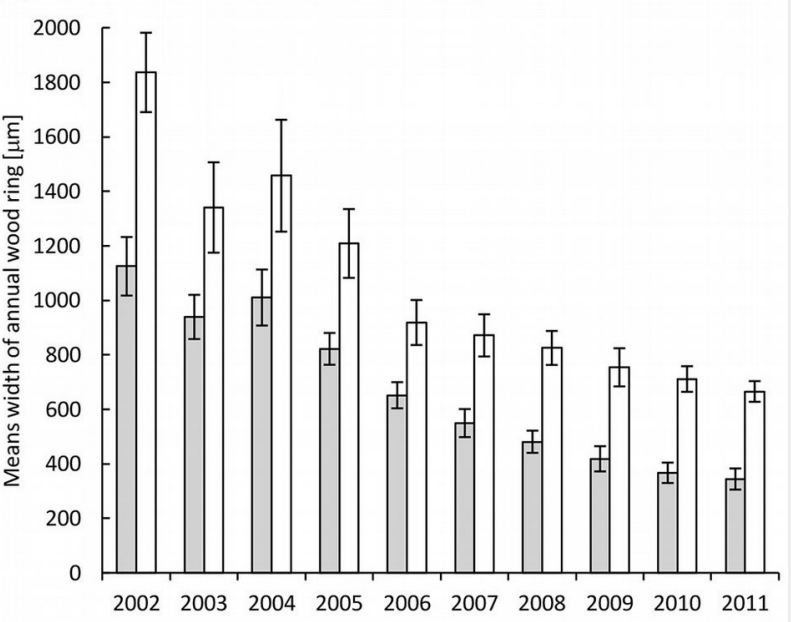

\section{Results}

Morpho-anatomical analysis of wood variation

In both health classes, the annual tree rings formed during the progress of ash dieback comprised a well-developed zone of earlywood, whereas the zone of latewood was diminished (Fig. 1). Also, a decrease in the width of annual tree rings in acropetal direction (from the base of the trunk toward the crown) was observed (Fig. 2a). This trend was significantly more pronounced in dead trees, in which the disease process was more advanced. In the last ten years, a reduction in the width of annual tree rings (expressed as the mean over the trunk) was observed, decreasing from $1850 \mu \mathrm{m}$ in 2002 to $700 \mu \mathrm{m}$ in 2011 and from $1100 \mu \mathrm{m}$ to $400 \mu \mathrm{m}$ in dying and dead trees, respectively (Fig. 2 b).

The number of vessels along the boundary of the tree rings increased from the base of the trunk towards the crown (Fig. 3a). This increase was significantly lower in dead trees compared to dying ones (Tab. 2). The number of vessels in the annual tree ring (averaged over the trunk) increased in the last 10 years, from over twenty to more than thirty in dying trees, and from a dozen to more than twenty in dead trees (Fig. 3b). (the num- ily, reaching in the last year (2011) a value ber of vessels per $1 \mathrm{~mm}^{2}$ of annual tree of 13.1 per $\mathrm{mm}^{2}$ in dead trees and 8 per $\mathrm{mm}^{2}$ ring) increased from the base of the trunk in dying ashes (Fig. 3d).

towards the crown. There was a signifi- The diameter of the vessels along the cantly higher vessel density in dead trees trunk decreased in dying trees from $221 \mu \mathrm{m}$ compared to dying trees, from 4.8 to 8.7 at breast height to $150 \mu \mathrm{m}$ at the base of and from 3.7 to 6.3 per $\mathrm{mm}^{2}$, respectively the crown. In dead trees this trend was si(Fig. 3c, Tab. 2). In the last 10 years the milar, with the largest diameters $(206 \mu \mathrm{m})$ mean vessel density in annual tree rings observed $10 \mathrm{~m}$ below the crown (Fig. 4a).

Tab. 2 - Differences in wood characteristics between the two health classes (dead and dying) of ash trees affected by dieback after the Student's t-test. (*): $p<0.05$.

\begin{tabular}{|c|c|c|c|c|}
\hline Wood characteristics & $\begin{array}{l}\text { Health } \\
\text { class }\end{array}$ & Mean & Difference & $t$-statistics \\
\hline \multirow{2}{*}{$\begin{array}{l}\text { Mean width of the annual } \\
\text { tree rings }(\mathrm{mm})\end{array}$} & Dead trees & 670.92 & \multirow{2}{*}{388.08} & \multirow{2}{*}{$6.799^{*}$} \\
\hline & Dying trees & 1059.00 & & \\
\hline \multirow{2}{*}{ Number of vessels (n) } & Dead trees & 21.83 & \multirow{2}{*}{4.96} & \multirow{2}{*}{$5.098^{*}$} \\
\hline & Dying trees & 26.79 & & \\
\hline \multirow{2}{*}{ Diameter of vessels $(\mathrm{mm})$} & Dead trees & 185.81 & \multirow{2}{*}{7.36} & \multirow{2}{*}{$2.010^{*}$} \\
\hline & Dying trees & 193.17 & & \\
\hline \multirow{2}{*}{ Density of vessels $\left(\mathrm{n} \mathrm{mm}^{-2}\right)$} & Dead trees & 6.64 & \multirow{2}{*}{1.92} & \multirow{2}{*}{$3.941^{*}$} \\
\hline & Dying trees & 4.72 & & \\
\hline \multirow{2}{*}{$\begin{array}{l}\text { Sectional area of earlywood } \\
\text { vessels }\left(\mathrm{mm}^{2}\right)\end{array}$} & Dead trees & 0.63 & \multirow{2}{*}{0.16} & \multirow{2}{*}{$5.249^{*}$} \\
\hline & Dying trees & 0.79 & & \\
\hline \multirow{2}{*}{$\begin{array}{l}\text { Ratio of surface area of earlywood } \\
\text { vessels to the width of the annual } \\
\text { tree ring }(\%)\end{array}$} & Dead trees & 19.20 & \multirow[b]{2}{*}{5.79} & \multirow[b]{2}{*}{$4.252^{*}$} \\
\hline & Dying trees & 13.41 & & \\
\hline
\end{tabular}



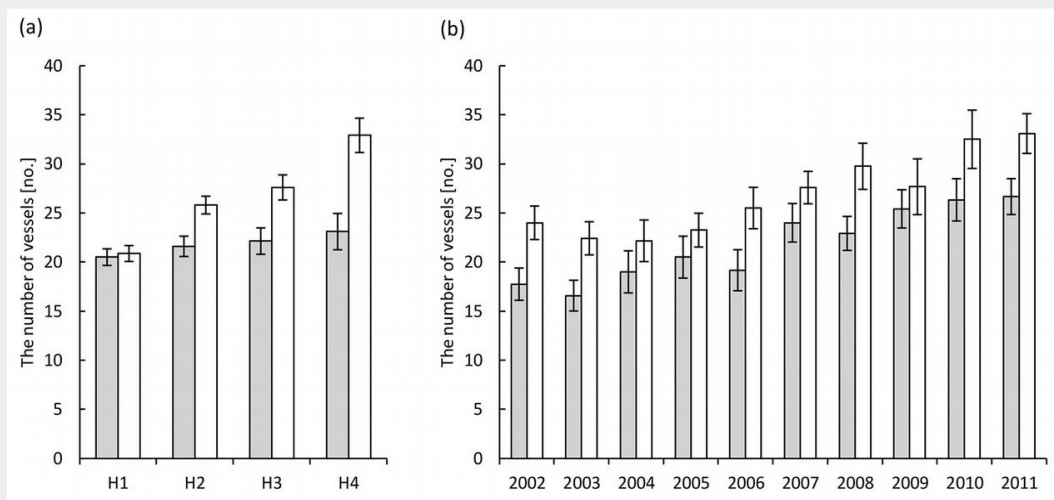

(c)

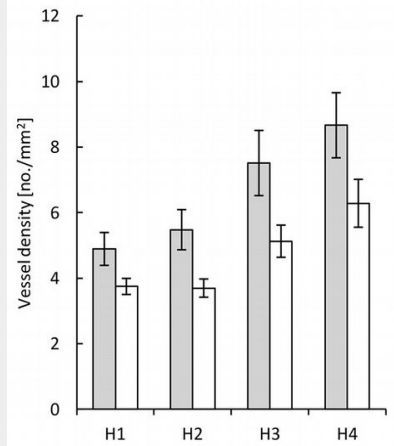

(d)

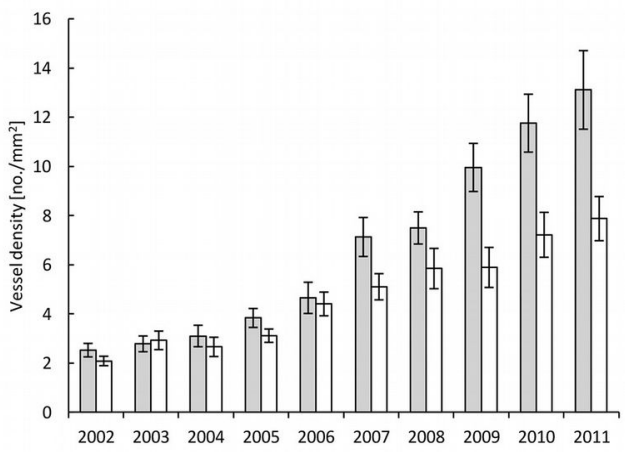

Fig. 3 - Number of vessels of earlywood along the boundary of annual growth ( $a, b)$ and vessel density of earlywood within annual increments (c, d) in the health classes of ash trees affected by dieback (white bars: dying trees; grey bars: dead trees). (a, c): different heights along the trunk ( $\mathrm{H}_{1}: 1.3 \mathrm{~m}$ above the ground; $\mathrm{H} 2: 10 \mathrm{~m}$ above the ground; $\mathrm{H}_{3}: 2 \mathrm{~m}$ below the crown base; $\mathrm{H}_{4}$ : close to the crown base); (b, d): different years over the period 2002-2011.

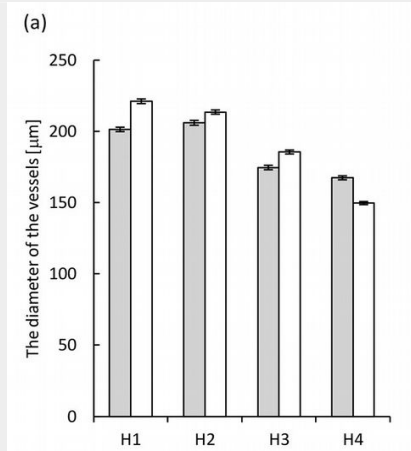

(c)
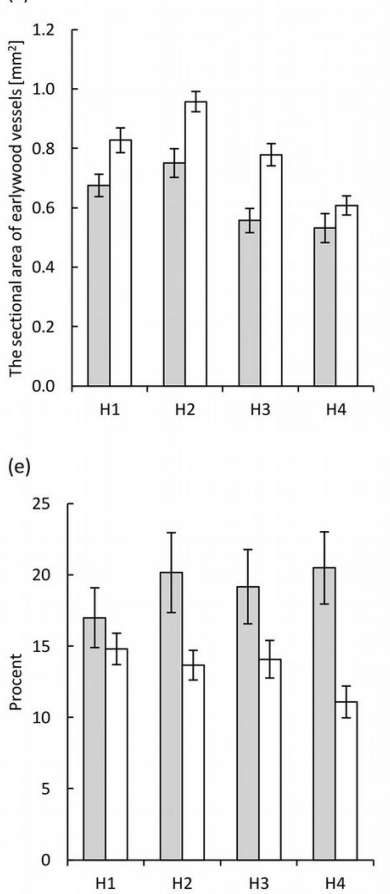

(b)

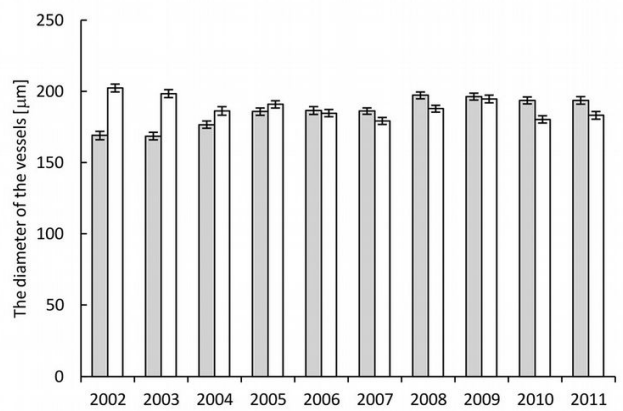

(d)

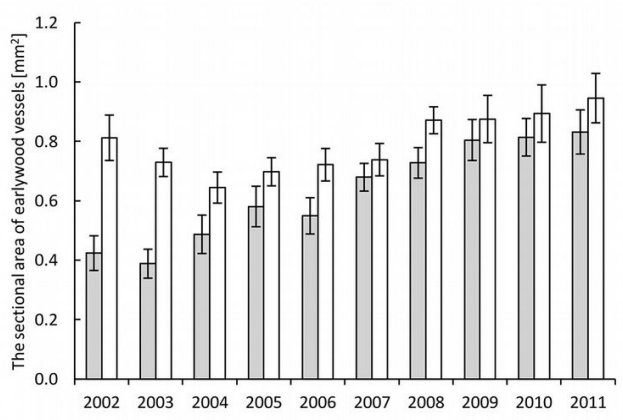

(f)

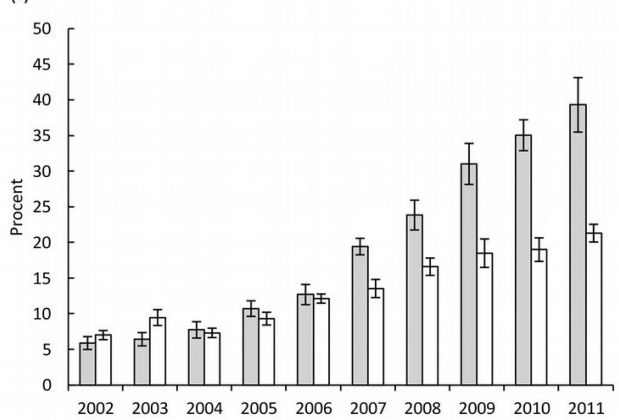

Fig. 4 - Diameter of earlywood vessels (a, b), cross sectional area of earlywood vessels (c, d) and the ratio of surface area of earlywood vessels to the width of the annual tree ring $(e, f)$ in the health classes of ash trees affected by dieback (white bars: dying trees; grey bars: dead trees). (a, c, e): different heights along the trunk $(\mathrm{H} 1: 1.3 \mathrm{~m}$ above the ground; $\mathrm{H}_{2}: 10 \mathrm{~m}$ above the ground; $\mathrm{H}_{3}: 2 \mathrm{~m}$ below the crown base; $\mathrm{H}_{4}$ : close to the crown base); (b, d, f): different years in the period 20022011. 
Fig. 5 - Alleles frequency for 6 nuclear

microsatellite loci examined in the health classes of ash trees affected by dieback (white bars: dying trees; grey bars: dead trees).

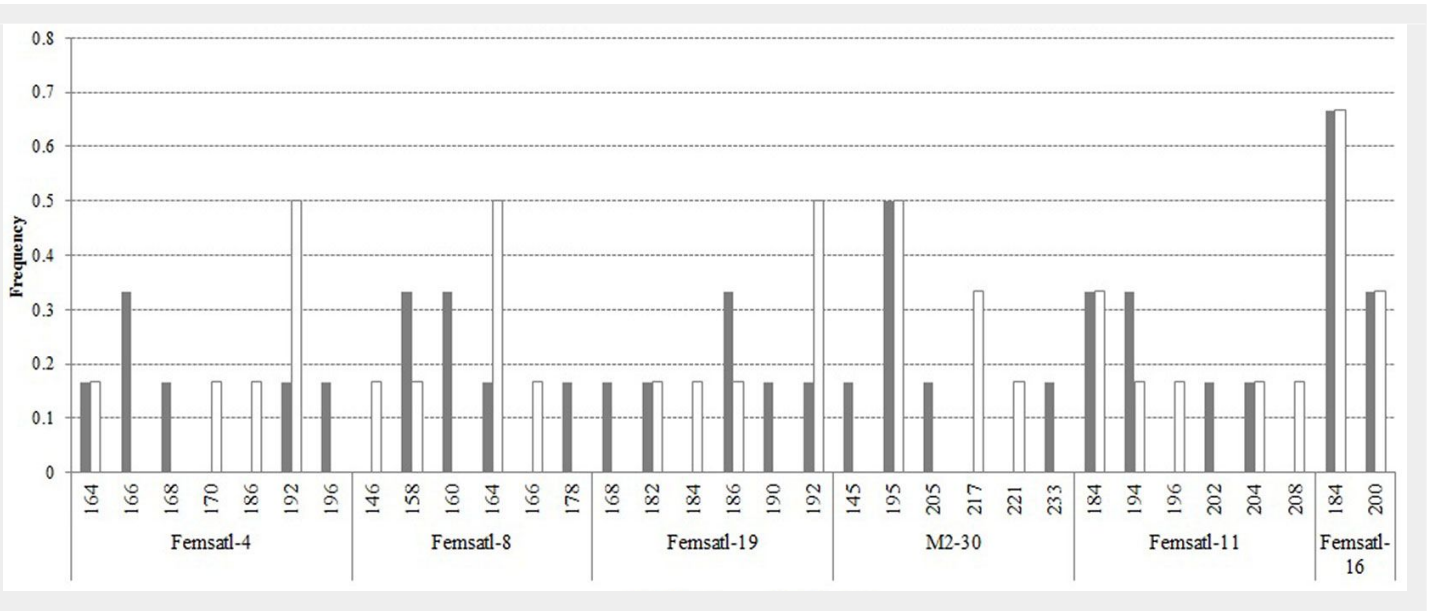

However, the vessel diameter under the crown was higher in dead trees and reached a mean value of $167 \mu \mathrm{m}$. In the last 10 years the mean vessel diameters (expressed as a mean for the trunk) fluctuated in both dying and dead trees, ranging from 202 to $179 \mu \mathrm{m}$ and from 196 to $168 \mu \mathrm{m}$ in dying and dead trees, respectively (Fig. $4 b)$.

The sectional area of earlywood vessels along the trunk in annual tree rings tends to reduce moving upwards toward the crown, with the highest values found at the height of $10 \mathrm{~m}$ below the crown ( 0.96 $\mathrm{mm}^{2}$ for dying trees and $0.75 \mathrm{~mm}^{2}$ for dead ashes, respectively - Fig. 4c, Tab. 2). In the last 10 years a higher cross-sectional area (mean over the trunk) was found in dying trees as compared with dead ashes. However, significant differences occurred in 2002-2004, 2006 and 2008 only (Fig. 4d).

The ratio of surface area of earlywood vessels to the width of the annual tree ring along the trunk fluctuated in the period considered (Fig. 4e). However, in dying trees it was significantly lower than in dead trees (Tab. 2). It was found to be the lowest under the canopy in dying trees, while in dead trees it was the lowest at breast height. During the last 10 years, the mean ratio of surface area of earlywood vessels to the width of the annual tree ring (mean for the trunk) increased more in dead trees than in dying ashes, and this trend was especially noticeable in the last 5 years of their lifespan (Fig. 4f).

\section{Genetic analysis of wood}

Based on the results of microsatellites analysis, we did not observe any polymorphism in the chloroplast loci. However, single private alleles have been detected for nuclear SSR loci, depending on the analyzed group of individuals (Fig. 5). The damaged trees had lower observed and expected number of alleles per locus (Tab. 3). Also, the number of private alleles was slightly higher in dead trees compared to the damaged trees $\left(A_{p}=1.883\right.$ and 1.5, respectively). The observed heterozygosity in the two health classes was the same $\left(H_{\circ}\right.$ $=0.889$ ), but the expected heterozygosity was higher in dead than in damaged trees

Tab. 3 - Estimates of genetic diversity parameters for dead and dying ash trees affected by dieback. $\left(n_{\mathrm{a}}, n_{\mathrm{e}}\right)$ : observed and expected allele number; $\left(A_{\mathrm{p}}\right)$ : private alleles; (I): information index; $\left(H_{\mathrm{o}}, H_{\mathrm{e}}\right)$ : observed and expected heterozygosity.

\begin{tabular}{lcccccc}
\hline $\begin{array}{l}\text { Health } \\
\text { class }\end{array}$ & $n_{\mathrm{a}}$ & $n_{\mathrm{e}}$ & $\boldsymbol{A}_{\mathrm{p}}$ & $\boldsymbol{I}$ & $\boldsymbol{H}_{\mathrm{o}}$ & $\boldsymbol{H}_{\mathrm{e}}$ \\
\hline Dead trees & 4.000 & 3.500 & 1.833 & 1.277 & 0.889 & 0.685 \\
Dying trees & 3.667 & 2.979 & 1.500 & 1.156 & 0.889 & 0.639 \\
\hline
\end{tabular}

$\left(H_{\mathrm{e}}=0.685\right.$ and 0.639 , respectively). The results of the AMOVA revealed that the two health classes of trees were not significantly divergent in terms of their genetic make-up $\left(F_{S T}=0.066 ; p>0.05\right.$ - data not shown).

\section{Discussion}

In this study, a marked modification of wood biometric traits was observed in ash trees affected by decline over the last 10 years of their lifespan. As expected, such changes were more pronounced in trees showing a more advanced disease process like the dead ash trees. The analysis of the width of annual tree rings along the trunk showed that the decline in radial growth is more prominent in the upper part of the trunk (below the crown) and gradually decreases moving toward the base. Further, we observed a more significant progression of the disease through time in dead ash trees as compared with dying trees. The above evidence might suggest that the weakening of water transport along the trunk could be involved in the dying of ash trees in the investigated area. Indeed, ash has ring-porous wood with large vessels in the earlywood and a very efficient conductive system; according to Hagen-Poisseuille's law, the amount of transported water is proportional to the fourth power of the vessel diameter (Tyree \& Zimmermann 2002, Tulik et al. 2010). On the other hand, their large vessels are exposed to embolism and cavitation which take place during the winter (Hacke \& Sperry 2001, Lens et al. 2013).

The formation of a suitable network of vessels during the annual production of wood rings is a necessary condition for an efficient water transport along the trunk. Our results suggests that dying trees pro- duced smaller annual rings with reduced vessel size (Fig. 4a, Fig. 4b) and increased density (Fig. 3C, Fig. 3d). This results in the deterioration of water supply to the crown, thus weakening the growth of apical meristems and leaves. Moreover, our results are consistent with the hypothesis that the observed reduction in vessel size and annual rings could be due to a disruption of the hormonal control of wood formation (in terms of interference in the polar auxin transport), progressively leading to the death of trees. Indeed, auxin is produced in apical meristems and young leaves and transported in basipetal direction to roots, promoting wood formation and controlling the density and size of the conductive elements in wood (Aloni \& Zimmermann 1983, Friml \& Palme 2002). Further, auxin strongly promotes the growth of roots (Zakrzewski \& Adamczyk 1991), which in turn produce cytokinins that move in the acropetal direction and stimulate the crown development (Van Staden \& Harty 1988), with a mechanism of positive feedback.

Genetic studies performed on plus-tree clones of $F$. excelsior in Sweden demonstrated a considerable genotypic variation among individuals. None of the clones were totally resistant to Hymenoscyphus fraxineus, but some trees exhibited a reduced susceptibility and still showed some resistance after 6 years of heavy infection pressure (Stener 2013). A study on the genetic variation in dieback resistance of Fraxinus excelsior carried out in Denmark using microsatellite markers (Lobo et al. 2015) proved no correlation between the inheritance of alleles at the Femsatl loci and tree susceptibility in terms of necrosis developed after inoculation with Chalara fraxinea. In this study, the two health 
groups of ash trees affected by dieback were screened at the Femsatl loci, finding no differences in their allele frequencies. We obtained similar results from the analysis of 55 samples of the same species showing different signs of dieback at various stages of infection (unpublished data). Only two alleles, one from locus Femsatl-11 (allele 208) and the second from locus Femsatl-19 (allele 190), were found only in a group of more resistant individuals. However, based on the results of this investigation, microsatellite markers did not show any correlation with the level of resistance to ash dieback, consistently with the neutral nature of this class of molecular markers. Other kinds of DNA-based markers like SNPs seems more suitable to differentiate tolerant versus susceptible ash trees, as recently demonstrated by Harper et al. (2016).

The interaction between European ash genotype and environmental conditions was previously assessed using RAPD markers in a Lithuanian population trial by Pliura \& Baliuckas (2007), who reported a high genetic variation within populations affecting the adaptive potential and competitive ability of the studied trees. High levels of genetic variation allows the ash population to maintain sufficiently high plasticity and adaptability to the changing environmental conditions. In this study, we found a fairly high (though not significant) levels of genetic divergence $\left(F_{S T}=0.066\right)$ between the two health groups of trees, even though they belong to the same population. Previous studies based on nuclear and chloroplast DNA markers showed a level of genetic divergence among Polish common ash populations higher to that found for Angiosperms ( $G_{\mathrm{ST}}=0.198$ vs. 0.110 , respectively - Hamrick et al. 1992, Nowakowska et al. 2004). Indeed, a transition zone between chloroplast microsatellite DNA haplotypes has been reported in Poland, which may suggest genotypic richness of common ash populations (Heuertz 2003).

Further studies based on DNA polymorphism performed on larger groups of trees may help to understand the genetic basis of the pathogen tolerance developed by some common ash trees.

\section{Conclusions}

In this study, we investigated the variation of the wood structure along the trunk of ash trees affected by ash dieback. Our results revealed that: (i) the reduction in width of annual tree rings in dead trees is much more conspicuous in the upper part of the trunk; (ii) the number of earlywood vessels in the upper part of the trunk is significantly different between dead and dying trees. Moreover, our results are in agreement with the hypothesis proposed by Aloni \& Zimmermann (1983). The above evidences suggest that the ash dying process could start at the top of the trunk, perhaps in the crown, then moving towards its base. We hypothesized that this could be the consequence of the disruption of the hormonal control of wood formation due to the pathogen, leading to a restricted water supply to the crown and thus weakening the growth of apical meristems and leaves. However, further study of the root system of diseased trees are needed to better understanding such mechanism.

The genetic analysis of wood of dying and dead ash trees using both chloroplast and microsatellite markers did not reveal any correlation between tree genotype and phenotype. However, the high variability detected and the presence of private alleles suggests a high genetic variation possibly associated with a higher adaptive potential for ash trees in unfavorable environmental conditions.

\section{Acknowledgments}

MT conceived the study, carried out the anatomical analyses and helped to draft the manuscript; JZ carried out the field study and helped to draft the manuscript; JA performed the statistical analysis and helped to draft the manuscript; AT and JN carried out the genetic surveys and helped to draft the manuscript; BY helped to draft the manuscript.

The authors thank Ms. Aissa Zakrzewska for language revision. We acknowledge Mr. Jan Wisniewski and Mr. Mariusz Kielek's assistance during wood samples collection.

\section{Disclosure statement}

No potential conflict of interest was reported by the authors.

\section{References}

Aloni R, Zimmermann MH (1983). The control of vessel size and density along the plant axis. A new hypothesis. Differentiation 24: 203-208. doi: 10.1111/j.1432-0436.1983.tb01320.x

Bakys R, Vasaitis R, Barklund P, Ihrmark K, Stenlid J (2009). Investigations concerning the role of Chalara fraxinea in declining Fraxinus excelsior. Plant Pathology 58: 284-292. - doi: 10.1111/j. 1365-3059.2008.01977.x

Baral HO, Queloz V, Hosoya T (2014). Hymenoscyphus fraxineus, the correct scientific name for the fungus causing ash dieback in Europe. IMA Fungus 5 (1): 79-80. - doi: 10.5598/imafun gus.2014.05.01.09

Brasier CM (1991). Ophiostoma novo-ulmi sp. nov., a causative agent of current Dutch elm disease pandemics. Mycopathologia 115: 151161. - doi: $10.1007 / B F 00462219$

Brasier CM, Cooke DEL, Duncan JM (1999). Origin of a new Phytophthora pathogen through interspecific hybridization. Proceedings of the National Academy of Sciences USA 96 (10): 5878-5883. - doi: 10.1073/pnas.96.10.5878

Bricker JS, Stutz JC (2004). Phytoplasmas associated with ash decline. Journal of Arboriculture 30: 193-199. [online] URL: http://asu.pure.else vier.com/en/publications/phytoplasmas-associa ted-with-ash-decline

Corcuera L, Camarero JJ, Sisó S, Gil-Pelegrin E (2006). Radial-growth and wood-anatomical changes in over aged Quercus pyrenaica coppice stands: functional responses in a new Me- diterranean landscape. Trees 20: 91-98. - doi: 10.1007/s00468-005-0016-4

Digby J, Wareing PE (1966). The effect of applied growth hormones on cambial division and the differentiation of the cambial derivatives. Annals of Botany 30: 539-548. - doi: 10.1093/ox fordjournals.aob.a084095

Ellmore GS, Ewers FW (1986). Fluid flow in the outermost xylem increment of a ring-porous tree, Ulmus americana. American Journal of Botany 73: 1771-1774. - doi: 10.2307/2444244

Friml J, Palme K (2002). Polar auxin transportold questions and new concepts? Plant Molecular Biology 49: 273-84. - doi: 10.1023/A:10152489 26412

Gil W, Lukaszewicz J, Paluch R, Zachara T (2006). Zamieranie jesionu - rozmiar problemu. [Ash dieback - the range of the problem]. Las Polski 5: 19. [in Polish]

Gärtner H, Schweingruber FH (2013). Microscopic preparation techniques for plant stem analysis. Verlag Dr. Kessel, Remagen, Germany, pp. 78.

Hacke UG, Sperry JS (2001). Functional and ecological xylem anatomy. Perspectives in Plant Ecology, Evolution and Systematics 4 (2): 97115. - doi: 10.1078/1433-8319-00017

Hamrick JL, Godt MJW, Sherman-Broyles SL (1992). Factors influencing levels of genetic diversity in woody plant species. New Forests 6: 95-124. - doi: 10.1007/BF00120641

Harper AL, Mckinney LV, Nielsen LR, Havlickova L, Li Y, Trick M, Fraser F, Wang L, Fellgett A, Sollars ES, Janacek SH, Downie JA, Buggs RJ, Kjær ED, Bancroft I (2016). Molecular markers for tolerance of European ash (Fraxinus excelsior) to dieback disease identified using Associative Transcriptomics. Scientific Reports 6 (1): 1235773. - doi: 10.1038/srep19335

Heuertz M (2003). Population genetics structure in common ash: a focus on southeastern European genetic resources. PhD thesis, Luxemburg, Free University of Brussels, Public Research Centre Gabriel Lippmann 2003, Belgium, pp. 156.

Jacobs WP (1952). The role of auxin in the differentiation of xylem around a wound. American Journal of Botany 39: 301-309. - doi: 10.2307/24 38258

Kirisits T, Freischlang C (2012). Ash dieback caused by Hymenoscyphus pseudoalbidus in a seed plantation of Fraxinus excelsior in Austria. Journal of Agricultural Extension and Rural Development 4: 184-101. [online] URL: http:// www.academicjournals.org/journal/JAERD/artic le-abstract/77EDCBD3612

Kowalski T, Holdenrieder O (2009). The teleomorph of Chalara fraxinea. Forest Pathology 39: 304-308. - doi: 10.1111/j.1439-0329.2008.00589.x Kowalski T (2006). Chalara fraxinea sp. nov. associated with dieback of ash (Fraxinus excelsior) in Poland. Forest Pathology 36: 264-270. - doi: 10.1111/j.1439-0329.2006.00453.x

Lens F, Tixier A, Cochard H, Sperry JS, Jansen S, Herbette $S$ (2013). Embolism resistance as a key mechanism to understand adaptive plant strategies. Current Opinion in Plant Biology 16: 287292. - doi: 10.1016/j.pbi.2013.02.005 Little CHA, Pharis RP (1995). Hormonal control of radial and longitudinal growth in the tree stem. In: "Plant Stems: Physiology and Functional 
Morphology" (Gartner B ed). Academic Press, San Diego, CA, USA, pp. 281-319.

Lobo A, McKinney LV, Hansen JK, Kjr ED, Nielsen LR (2015). Genetic variation in dieback resistance in Fraxinus excelsior confirmed by progeny inoculation assay. Forest Pathology 45: 379-387. - doi: 10.1111/efp.12179

Muday GK, Morphy AS (2002). An emerging model of auxin transport regulation. The Plant Cell 14: 293-299. - doi: 10.1105/tpc.140230

Nowakowska J, Jablonowski S, Mockeliunaite R, Bieniek J (2004). Genetic variability within and among Polish and Lithuanian populations of common ash (Fraxinus excelsior L.) based on RAPD analysis. Baltic Forestry 10: 57-64. [online] URL: http://www.researchgate.net/ publication/259842044

Pautasso M, Aas G, Queloz V, Holdenrieder O (2013). European ash (Fraxinus excelsior) dieback - a conservation biology challenge. Biological Conservation 158: 37-49. - doi: 10.1016/j.bio con.2012.08.026

Peakall R, Smouse PE (2006). GenAlEx 6: genetic analysis in Excel. Population genetic software for teaching and research. Molecular Ecology Resources 6: 288-295. - doi: 10.1111/j.1471-8286. 2005.01155.x

Pliura A, Baliuckas V (2007). Genetic variation in adaptive traits of progenies of Lithuanian and western European populations of Fraxinus excelsior L. Baltic Forestry 13 (1): 28-38. [online] URL: http://www.researchgate.net/publication/ 262600118

Pliura A, Lygis V, Marčiulyniene $D$, Suchockas V, Bakys R (2015). Genetic variation of Fraxinus excelsior half-sib families in response to ash dieback disease following simulated spring frost and summer. iForest 9: 12-22. - doi: 10.3832 /ifor1514-008

Sachs T (1981). The control of the patterned differentiation of vascular cambium. Advances in Botanical Research 9: 152-255. - doi: 10.1016/ So065-2296(08)60351-1

Stener LG (2013). Clonal differences in susceptibility to the dieback of Fraxinus excelsior in southern Sweden. Scandinavian Journal of Forest Research 28: 205-216. - doi: 10.1080/02827 581.2012.735699

Stocki J (2001). Przyczyny zamierania drzew i drzewostanów jesionowych w Polsce. [The causes of trees dieback and whole stands of ash in Poland]. Glos Lasu 4: 17-19. [in Polish]

Sutherland BG, Belaj A, Nier S, Cottrell JE, Vaughan PS, Hubert J, Russell K (2010). Molecular biodiversity and population structure in common ash (Fraxinus excelsior L.) in Britain: implications for conservation. Molecular Ecology 19: 2196-2211. - doi: 10.1111/j.1365-294X.2009. 04376.x

Thomsen IM, Skovsgaard JP (2012). Silvicultural strategies for forest stand with ash dieback. Forstschutz Aktuell 55: 18-20. [online] URL: http://www.forskningsdatabasen.dk/en/catalog /2193067807

Tulik M, Marciszewska K, Adamczyk J (2010). Diminished vessel diameter - as a possible factor in the decline of European ash (Fraxinus excelsior L.). Annals of Forest Science 67: 103108. - doi: 10.1051/forest/2009084

Tyree MT, Zimmermann MH (2002). Xylem structure and the ascent of sap. Springer-Verlag, Berlin, Germany, pp. 283.

Uggla C, Mellerowicz EJ, Sundberg B (1998). Indole-3 acetic acid controls cambial growth in
Scots pine by positional signaling. Plant Physiology 117: 113-121. - doi: 10.1104/pp.117.1.113

Van Staden J, Harty AR (1988). Cytokinins and adventitious root formation. In: "Adventitious root formation in cuttings" (Davies TD, Haissig $\mathrm{BE}$, Sankhla N eds). Dioscorides Press, Oregon, USA, pp. 185-201.

Ward K, Ostry M, Venette R, Palik B, Hansen M, Hatfield M (2006). Assessment of black ash (Fraxinus nigra) decline in Minnesota. In: Proceedings of the " 8 th Annual Forest Inventory and Analysis Symposium" (McRoberts RE, Reams GA, Van Deusen. McWilliams WH eds). Monterey (CA, USA) 16-19 Oct 2006. Gen. Tech. Rep. WO-79, USDA Forest Service, Washington, DC, USA, pp. 115-120. [online] URL: http:// www.nrs.fs.fed.us/pubs/gtr/gtr_wo079/gtr_wo 079 115.pdf

Wolpert L (1996). One hundred years of positional information. Trends in Genetics 12: 359364. - doi: 10.1016/S0168-9525(96)80019-9

Zakrzewski J, Adamczyk J (1991). Effect of apical supplying IAA upon the induced rhizogenesis in isolated shoot segments of Acer pseudoplatanus L. Annals of Warsaw Agricultural University-SGGW Forestry and Wood Technology 42: 71-75.

Zakrzewski J (1991). Effect of indole-3-acetic acid (IAA) and sucrose on vessel size and density in isolated stem segments of oak (Quercus robur). Physiologia Plantarum 81: 234-238. - doi: 10.1111/ j.1399-3054.1991.tb02135.x

Zimmermann MH (1983). Xylem structure and the ascent of sap. Springer-Verlag, Berlin, Germany, pp. 143. 